\title{
Začetek dolgoročne elektronske hrambe v slovenski upravi: trenutno stanje in scenariji prihodnosti
}

\author{
UDK: 35:004.9:651.51/.57 \\ Mitja Dečman \\ Univerza v Ljubljani, Fakulteta za upravo \\ mitja.decman@fu.uni-lj.si
}

\begin{abstract}
IZVLEČEK
Vedno večje število dokumentov $v$ digitalni obliki ob vsakodnevnem poslovanju javne uprave povzroča, da bo treba razmisliti o uvedbi ustreznega načina dolgoročne hrambe digitalnih dokumentov ob upoštevanju vnaprej določenih rokov hrambe. Ti roki so v slovenski javni upravi dokaj natančno določeni, saj temeljijo na klasifikacijskih načrtih, ki so za organe javne uprave obvezni po Uredbi o upravnem poslovanju. Zakonodaja, sprejeta v letu 2006, je slovenski javni upravi in zasebnemu sektorju dokončno odprla pot $v$ popolno elektronsko poslovanje in dolgoročno hrambo ter postavila podlago za dokončno zmanjševanje ali ukinjanje papirne dokumentacije. Kako je slovenska javna uprava ob taki pravni podlagi pripravljena na omenjene izzive, kažejo v članku predstavljeni rezultati obsežne empirične raziskave, izvedene v letu 2007. Le-ta opozarja na korake, ki jih bodo morali tako organi javne uprave kot vlada napraviti v bližnji prihodnosti za uspešno uvedbo dolgoročne digitalne hrambe $v$ javni upravi.
\end{abstract}

Ključne besede: elektronski dokumenti, dolgoročna hramba, digitalni arhiv, upravljanje z dokumenti

\section{Uvod}

Dokumenti, podatki, zapisi, različni informacijski in kulturni artefakti se danes pogosto pretvarjajo $v$ digitalno obliko, vsakodnevno pa se že ustvarjajo $v$ tej obliki. Informacijska družba vsako sekundo izkorišča informacijsko tehnologijo (IT) na najrazličnejše načine, vsak segment družbe na svoj način in 
Mitja Dečman

Začetek dolgoročne elektronske hrambe v slovenski upravi:

trenutno stanje in scenariji prihodnosti

s svojimi specifičnimi cilji. Prednosti IT-ja pa se ne izkorišča le ob vsakdanjem delu z elektronskimi podatki, mnoge prednosti tehnologije so tudi $\vee$ arhivski stroki. Med pozitivnimi prednostmi naj omenimo možnost kakovostnejšega poslovanja arhivov, večjo dostopnost (24 ur na dan, sedem dni v tednu, oddaljen dostop, različni odjemalci) in boljše ter hitrejše iskanje z ustreznimi iskalnimi pripomočki; negativne posledice pa so večja odgovornost arhivov, večje potrebe po IT-ju, strokovnjakih in visokem tehnološkem znanju, večji stroški, saj se poleg klasičnega arhiva, ki je zaradi obstoječe količine papirnih dokumentov praktično vedno potreben, dodaja še elektronski, ki marsikaj uvaja na novo; skratka, več dela za arhive zaradi aktivnega načela elektronske hrambe "hramba ves čas".

Pri vsem tem neverjetnem naraščanju količine podatkov pa se pojavi problem dolgoročne hrambe teh podatkov. S hrambo digitalnih podatkov namreč človeštvo nima velikih izkušenj. $\vee$ zgodovini sta hramba in arhiviranje pomenila zagotavljanje nespremenjene oblike različnih stvari. Vendar je $\vee$ digitalnem svetu ta koncept močno spremenjen in od družbe praktično zahteva, da od začetka uvaja sistematičen pristop do omenjenega problema (Garrett \& Waters, 2004). Celo arhivska načela, ki so se razvijala skozi stoletja, bi po mnenju nekaterih morali opredeliti na novo (Delmas, 2001).

Če ohranjamo digitalne podatke $v$ izvirni obliki brez sprememb, bo dostop do njih sčasoma vse težji in težji, če ne celo nemogoč, kar za klasične oblike (papir, pergament, kamen ipd.) ne velja $\vee$ enaki meri. Izjava enega od začetnikov elektronske hrambe se glasi: "Digitalni dokumenti trajajo večno - ali pa 5 let, kar pač pride prej" (Rothenberg, 1998). Pomislimo samo na dostopanje do podatkov, shranjenih na prvi disketah velikih formatov. Ne samo, da je večina takih nosilcev neberljivih, težava je tudi $\vee$ tem, da $\vee$ današnjih računalnikih ni naprav, ki bi jih brale. Slavni angleški projekt "The Domesday Project" iz leta 1986 se je končal ravno s takim tragičnim koncem (The Digital Preservation Coalition, 2006). Toda tudi če bi danes uspeli izumiti elektronski nosilec, ki bi ohranil podatke več sto ali tisoč let, bi težava še vedno ostala pri formatih za hrambo podatkov, ki se nenehno spreminjajo. In čeprav elektronsko arhiviranje lahko opredelimo kot zadnjo fazo življenjskega cikla dokumenta, lahko brez zadržkov zatrdimo, da gre za pomembnejši del celotnega življenjskega cikla dokumenta (Novak M., 2004). 


\section{Mitja Dečman \\ Začetek dolgoročne elektronske hrambe v slovenski upravi: trenutno stanje in scenariji prihodnosti}

\section{Elektronsko arhiviranje}

Ob vsesplošni razširjenosti računalnikov in IT-ja tako $v$ zasebnem sektorju kot $v$ javni upravi vedno več dokumentov nastaja $v$ elektronski obliki. Prednost le-teh je lažje, hitrejše in cenejše ustvarjanje, večja mobilnost, obdelava, organiziranje in upravljanje, vendar pa se hkrati pojavlja problem zanesljivosti, avtentičnosti, verodostojnosti, dostopnosti in hrambe. Ko govorimo o dolgoročni hrambi dokumentov $v$ digitalni obliki, se kompleksnost problema ne pokaže pri gradivu ali arhivskem gradivu, temveč je že za gradivo, katerega rok hrambe je 5 ali 10 let, potrebna skoraj enako dobra, zahtevna in draga rešitev kot za arhivsko ali trajno digitalno gradivo. Da se institucije izognejo popolni izgubi pregleda nad dokumentacijo, uvajajo elektronske sisteme za upravljanje z dokumenti in sisteme za delovne tokove (workflow systems). Le-ti omogočajo upravljanje dokumentov skozi vse faze življenjskega cikla dokumentov, do zadnjega koraka, tj. uničenja oz. arhiviranja. Arhiviranje mora tako biti vidik, ki je vseskozi prisoten in na katerega je treba misliti že ob nastanku dokumenta, kajti elementi in lastnosti, ki jih dokument pridobi ob nastanku, se ohranjajo skozi celoten življenjski cikel (Žumer, 2002). Do take ugotovitve je prišla tudi nedavna raziskava Mind the Gap v Veliki Britaniji (The Digital Preservation Coalition, 2006). Funkcije arhiva lahko opredelimo kot ohranjanje kulturne dediščine, ohranjanje dokazne vrednosti in interpretacijo sedanjosti za prihodnost. Pri tem je treba ohraniti fizične nosilce dokumentov, zmožnost interpretacije kodiranja dokumentov, zmožnost interpretacije kontekstualne dimenzije dokumenta (Blanchette J. F., 2003).

Elektronsko arhiviranje in sistemi za elektronsko arhiviranje niso potrebni zgolj za samo dolgoročno hrambo elektronskih dokumentov, temveč zajemajo tudi metode vnašanja dokumentov $v$ arhiv, ravnanje $z$ arhiviranimi dokumenti, vzdrževanje dokumentov $v$ arhivu ter omogočanje dostopa in branja arhiviranih dokumentov (Lavoie, 2000). Med pomembnejše funkcije digitalne hrambe sodi zaradi drugačnih lastnosti digitalne od klasične oblike prav gotovo zagotavljanje avtentičnosti in celovitosti. Avtentičnost pomeni, da dokument je to, kar v svoji vsebini trdi, da naj bi bil (MacNeil, 2001). Celovitost pa se nanaša na dejstvo, da je dokument celovit in da njegova vsebina ni bila na kakršenkoli način spremenjena (International Council on Archives, Committee on Current Records in an Electronic Environments, 2005, str. 12). Sama digitalna oblika namreč ne zagotavlja zaščite pred spreminjanjem vsebine, kakor smo tega 
Mitja Dečman

Začetek dolgoročne elektronske hrambe v slovenski upravi:

trenutno stanje in scenariji prihodnosti

navajeni pri papirni obliki. Bistveni razlog za to je, da je vsebina pri papirni obliki neločljivo vezana na nosilec, $v$ digitalni obliki pa ne.

Vse omenjene lastnosti digitalne oblike vodijo do dejstva, da dokument lahko ohranimo le, če se nosilec, na katerem je shranjen dokument, neprestano osvežuje (kopiranje na nov nosilec oziroma osveževanje le-tega) in se zapis (format) dokumenta prilagaja najnovejši tehnologiji ali pa se neprestano izdeluje tehnologija, ki zna predstaviti dokument $\vee$ njegovi prvotni obliki. Prvemu načinu pravimo migracija, drugemu pa emulacija. Migracija je ponavadi zapletena, draga in časovno zahtevna operacija (Dollar, 1998), emulacija pa zahteva napredno znanje za izdelavo emulatorjev, ki omogočajo prikaz dokumenta $\vee$ prvotnem formatu na katerikoli platformi $\vee$ prihodnosti in ohranjajo izvirni "videz in občutek" (look and feel) (Rothenberg, 1998).

\section{Pravna podlaga za elektronsko hrambo v Sloveniji}

Tako $\vee$ svetu kot $\vee$ Sloveniji se obstoječa zakonodaja prilagaja novim tehnološkim izzivom, kar velja tudi za ravnanje z dokumentarnim gradivom in arhiviranje, hkrati pa krovni zakoni tehnologije namenoma ne določajo in omejujejo in so s tem omogočajo prihajajoče nove tehnologije. To regulativo danes $v$ Sloveniji tvori trojček, ki vključuje Zakon o varstvu dokumentarnega in arhivskega gradiva in arhivih (ZVDAGA, 2006), Uredbo zakona o varstvu dokumentarnega in arhivskega gradiva in arhivih (UVDAGA, 2006) in Enotne tehnološke zahteve (ETZ, 2006), ki so bile leta 2007 dopolnjene še s Kontrolnim seznamom za preverjanje usklajenosti notranjih pravil z ZVDAGA (KSpNP, 2007). Med najpomembnejše prav gotovo sodi Zakon o varstvu dokumentarnega in arhivskega gradiva ter arhivih (ZVDAGA, 2006), ki je nasledil obstoječi Zakon o arhivskih gradivih iz leta 1997. ZVDAGA tako tudi zapolni vrzel glede obsega elektronske oblike dokumentov, saj je Zakon o elektronskem poslovanju in elektronskem podpisu (ZEPEP, 2000) upošteval le dokumente, nastale $\vee$ elektronski obliki, in njihovo hrambo, ZVDAGA pa opredeli hrambo klasičnega in elektronskega, ki se lahko hrani klasično ali elektronsko. Tako lahko dokumente na ustrezen način pretvorimo iz papirne $v$ digitalno obliko, iz ene digitalne $v$ drugo (npr. obliko za dolgoročno hrambo, če je rok hrambe več kot 5 let) in takšne tudi hranimo. ZVDAGA vsebuje in poudarja "Načelo ohranjanja 


\section{Začetel Mitja Dečman trenutno stanje in scenariji prihodnosti}

dokumentarnega gradiva oziroma uporabnosti njegove vsebine«, kar pomeni, da hramba dokumentarnega gradiva zagotavlja ohranjanje izvirnega dokumentarnega gradiva ali uporabnosti njegove vsebine. Hrambi izvirnega dokumentarnega gradiva je zato enaka hramba zajetega gradiva (reprodukciji), če zagotavlja zajetemu gradivu vse učinke izvirnega gradiva (uporabnost vsebine gradiva). Hramba izvirnika tako ni več nujna (dovoljena je npr. zgoraj omenjena migracija in osveževanje nosilcev). Zahteva se trajnost tega gradiva oziroma trajnost reprodukcije njegove vsebine, njuna celovitost (nespremenljivost in integralnost), urejenost, dokazljivost izvora dokumentarnega gradiva (provenience) ter dostopnost ves čas trajanja hrambe. Zakon in uredba pa ne opredeljujeta tehničnim meril, kar določajo šele Enotne tehnološke zahteve (ETZ, 2006), v katerih so opredeljeni postopki za zajem, pretvorbo ter aktivno hrambo gradiva in temeljijo na modelu Moreq (Arhiv Republike Slovenije, 2005), ki je rezultat projekta Evropske unije. Novost ZVDAGA so tudi notranja pravila, ki jih mora predpisati vsaka oseba, ki izvaja elektronsko hrambo (ZVDAGA, 2006, čl. 18). Pravna veljavnost shranjenih elektronskih dokumentov (enakost izvirniku) se glede na stanje notranjih pravil tako obravnava na tri različne načine (ZVDAGA, 2006, čl. 32, 33). ZVDAGA uvaja še eno novost na področju hrambe elektronskih dokumentov, saj lahko lastniki dokumentov najamejo ponudnika zajema in hrambe dokumentov, programske in strojne opreme ali drugih spremljevalnih storitev (t. i. zunanje izvajanje ali outsourcing). Ti ponudniki se morajo registrirati (registracija je obvezna), možna pa je tudi akreditacija, ki opredeljuje strožje pogoje delovanja in nadzora, ki jih določa in nadzoruje državni arhiv, in je nujna za ponudnike storitev javnopravnim osebam.

\section{Stanje na podlagi rezultatov empirične raziskave}

Na področju digitalnega arhiviranja je bilo do sedaj narejenih zelo malo empiričnih raziskav, saj je področje še dokaj nerazvito. Največ dela je bilo opravljenega pri različnih projektih zlasti teoretične in tehnične narave ter pri razvoju aplikacij, ki na podlagi znanstvenih dognanj, različnih standardov in izkušenj s klasičnim arhiviranjem ponujajo prve rešitve dolgotrajnega digitalnega arhiviranja. Med najbolj znanimi naj omenimo empirično raziskavo $v$ Veliki Britaniji iz leta 2005, ki analizira stanje na tem področju $\vee$ tej državi (The Digital Preservation Coalition, 2006), raziskavo podjetja Cohasset Associates Inc., 


\section{Mitja Dečman}

\section{Začetek dolgoročne elektronske hrambe v slovenski upravi: trenutno stanje in scenariji prihodnosti}

organizacije AlIM International in organizacije ARMA International, ki se je osredotočila na upravljanje dokumentov z vidika dolgoročne dosegljivosti teh dokumentov (Cohasset associates inc., 2005), ter raziskavo Univerze v Marylandu, ki je analizirala stanje upravljanja elektronskih dokumentov in njihove dolgoročne hrambe $\vee$ ZDA (Center for Information Policy, University of Maryland, 2005).

Raziskava stanja $v$ Sloveniji je bila opravljena $\vee$ začetku leta 2007. Ciljno populacijo so sestavljale po skupinah občine ${ }^{\mathbf{1}}(\mathrm{N}=193)$, upravne enote $(N=58)$, ministrstva in organi $v$ sestavi $(N=55)$, univerze in fakultete $(N=43)$ ter preostala državna uprava ( $N=112)$ : najvišji organi državne uprave $(N=5)$, vladne službe $(N=16)$, druge ustanove, agencije, komisije in zavodi $(N=21)$, Zavod za zdravstveno zavarovanje Slovenije in enote $(\mathrm{N}=7)$ ter Center za socialno delo $\mathrm{RS}$ in enote $(\mathrm{N}=63)$. Analiza stanja upravljanja dokumentov $v$ elektronski obliki je pokazala, da anketirani organi (poleg veljavne zakonodaje) za urejanje ravnanja z dokumenti in zapisi v večji meri (45 \%) uporabljajo še dodatna pravila, navodila ali strategije (Slika 1, levo). Še posebej pozitivno izstopajo ministrstva z organi $v$ sestavi in upravne enote. Roke hrambe določa večina anketiranih organizacij z izjemo univerz ter fakultet, ki negativno odstopajo (Slika 1, desno). $\checkmark$ skupini občin in organov ostale državne uprave roke hrambe $v$ veliki meri določajo samo za papirne dokumente, drugod tudi za elektronske.

Uporaba klasifikacijskega načrta je skoraj 100-odstotna, tisti, ki ga še ne uporabljajo, pa uporabo načrtujejo. Izjema so zopet univerze in fakultete. Vodenje evidence dokumentarnega gradiva je urejeno večinoma elektronsko, med anketiranimi pa prednjačijo upravne enote. Od tistih, ki evidenco dokumentov vodijo elektronsko, je 78 \% takih, ki uporabljajo sistem za upravljanje dokumentov. Za zagotavljanje avtentičnosti dokumentov $\vee$ elektronski obliki anketirani organi uporabljajo različne tehnike, nekatere celo tiskanje na papir. Največ se jih problema še ni lotilo, med odgovori pa so $v$ povprečju enako zastopane tehnike ustrezne tehnologije, ustreznih informacijskih sistemov in ustrezno urejenih poslovnih postopkov.

Digitalizacijo uporabljajo zlasti $v$ anketiranih upravnih enotah ter na ministrstvih z organi $v$ sestavi. Med njimi je $v$ javnem sektorju $55 \%$ anketiranih organov, ki kot pravno veljaven še vedno obravnavajo papirni izvirnik, drugi obravnavajo izvirnik in ustrezno digitaliziran dokument kot enakovredna.

1 Izbrane so občine z utečenim poslovanjem, torej tiste, ki delujejo že dalj časa. 
Slika 1: Uporaba dodatnih pravil ( $N=204$, levo) in določanje rokov hrambe ( $N=206$, desno)

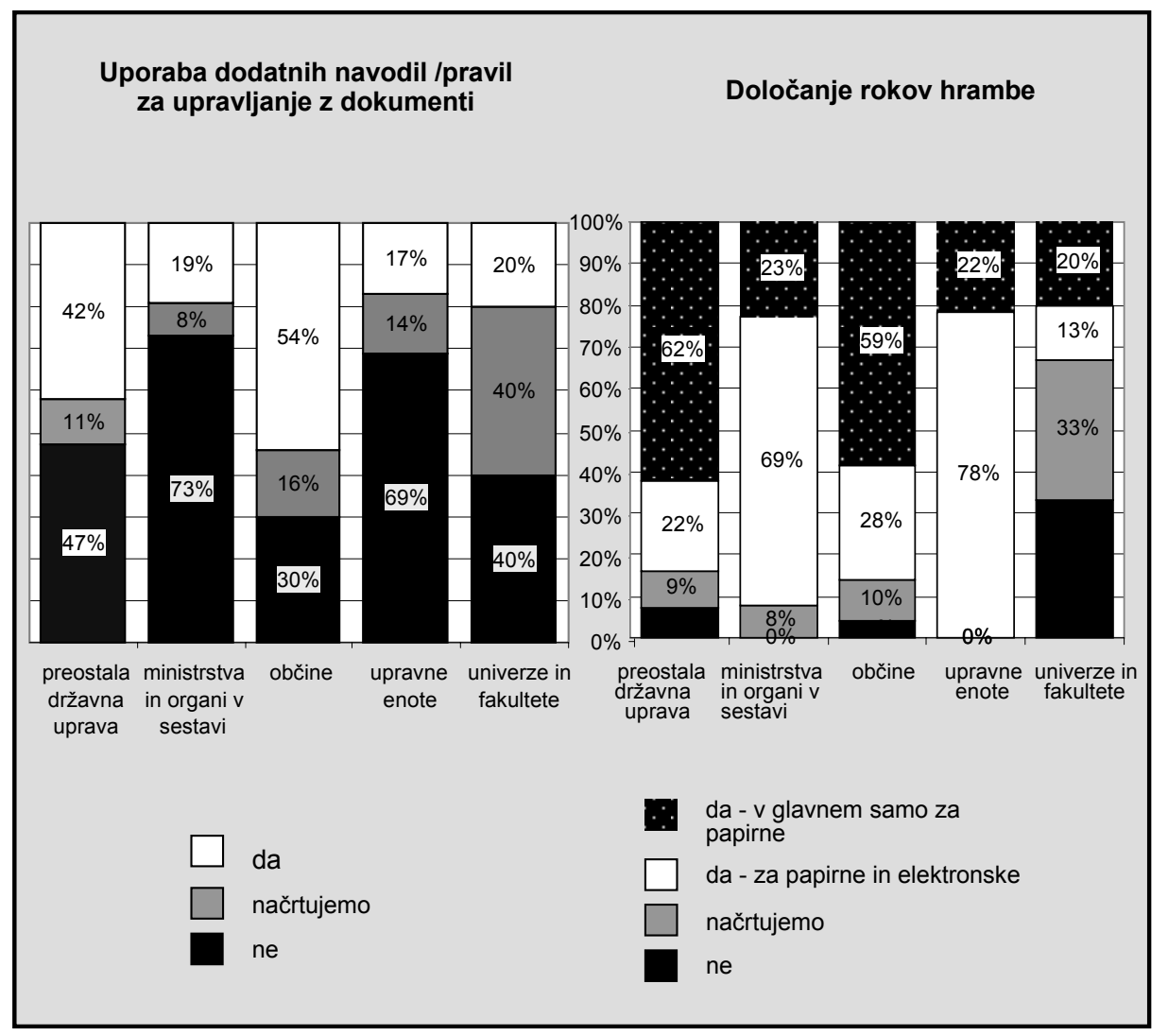

Mnogi organi uporabljajo interna pravila za ravnanje z elektronsko pošto, še posebej izstopajo upravne enote. Pri vprašanju, kako hranijo elektronsko pošto in priponke, preseneča, da večina organov (65 \%) elektronsko pošto in priponke tudi natisne na papir in z njimi ravna kot $s$ papirnatimi dokumenti. Največjo odgovornost za vsakodnevno upravljanje elektronskih dokumentov nosi vsak sam, je pa večji delež odgovornosti na posebej za to usposobljenih zaposlenih (največji delež imajo $v$ skupini anketiranih upravnih enot in ministrstev z organi $v$ sestavi). Približno tretjina organov meni, da so te odgovorne osebe dovolj usposobljene, skoraj polovica organizacij usposabljanje načrtuje, petina pa takšnih namenov sploh nima. Presenetljivo kar $\vee 15 \%$ anketiranih organov zasebnega sektorja ne čutijo potrebe po elektronski hrambi. Eden najpomembnejših meril načrtovanja dolgoročne hrambe je prav gotovo količina 


\section{Mitja Dečman}

\section{Začetek dolgoročne elektronske hrambe v slovenski upravi: trenutno stanje in scenariji prihodnosti}

obstoječih dokumentov $\vee$ elektronski obliki, ki jo je treba hraniti, in letno naraščanje te količine. Toda rezultati kažejo, da $50 \%$ anketiranih organov tega še ni storilo, 43 \% pa to še načrtuje. Brez pripravljene strategije oziroma načrta arhiviranja dokumentov $\vee$ elektronski obliki je skoraj polovica anketiranih organov. Delež tistih, ki so jo že pripravili, pa je $8 \%$, izstopa skupina univerz in fakultet, kjer takih s pripravljeno strategijo še ni, in skupina ministrstev z organi $\checkmark$ sestavi, kjer je največji delež takih, ki imajo pripravo take strategije $v$ načrtu. $V$ povprečju le četrtina organizacij ugotavlja, da sedanje organizacijske in tehnične rešitve zagotavljajo varno in dokazljivo elektronsko hrambo. Med tehnične faze elektronske hrambe prav gotovo sodi osveževanje nosilcev na fizični in migracija formatov na logični ravni. Iz rezultatov sledi zanimiva ugotovitev, da je osveževanje nosilcev pogosto, medtem ko je migracija tisti "kazalnik", kjer zasledimo najmanj odgovorov "da" in "načrtujemo". Finančna sredstva za elektronsko hrambo $v$ letne finančne načrte vključuje le malo organov (okoli $10 \%$ ). Lahko pa opazimo, da je takih organizacij več v tistih skupinah, kjer je na splošno več finančnih sredstev. Z namenom hrambe elektronskih dokumentov anketirani organi le-te največkrat kopirajo na prenosni nosilec ali pa kar natisnejo na papir (Slika 2, levo). V skupini upravnih enot in ministrstev opazimo tudi večjo uporabo arhivskih strežnikov ali arhivskih sistemov. Odstotek anketiranih organov, ki imajo jasno določene osebe, odgovorne za elektronsko hrambo, je $34 \%$. V tej skupini izstopajo upravne enote, $v$ skupini univerz in fakultet pa takih odgovornih oseb zaenkrat še nikjer ni določenih. $V$ organizacijah, kjer so določili tako osebo (ali več takih oseb), je najpogosteje kar zaposleni sam. $\vee$ javnem sektorju pomembno odgovornost poleg informatikov nosijo še arhivisti. Kot največje težave dolgoročne elektronske hrambe so različne skupine zelo različno ocenile stanje, tako da je težko poiskati skupne dejavnike med skupinami (Slika 2, desno). Izstopajo težave glede pomanjkanja ustreznih strojnih in programskih rešitev za elektronsko hrambo, na drugem mestu sta pomanjkanje finančnih virov in znanja. 
Slika 2: Tehnike ( $N=194$, levo) in ovire e-hrambe $(N=87$, desno)

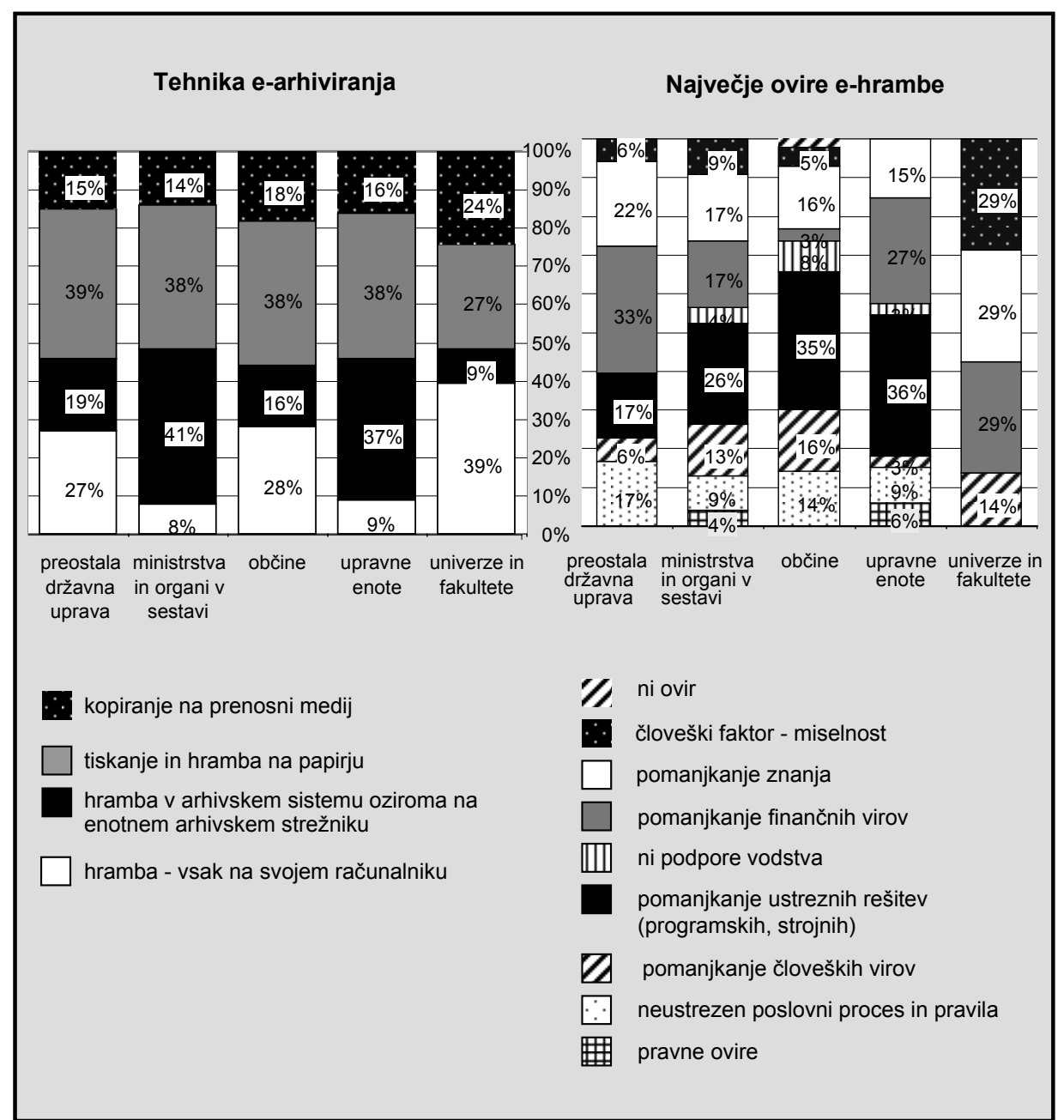

\section{Ugotovitve}

Slovenija je na dobri poti, da si zagotovi varno digitalno prihodnost in prihodnjim rodovom omogoči digitalno brskanje po preteklosti. Pravna podlaga je ena najnaprednejših $v$ svetu in tako javnemu kot zasebnemu sektorju zagotavlja ustrezno digitalno varnost. Podobno kot ugotavljajo druge raziskave $v$ svetu, pa $v$ slovenski upravi ne smemo računati na to, da bodo sprejeta zakonodaja in notranja pravila organov za dolgoročno elektronsko hrambo dovolj za verodostojno 


\section{Mitja Dečman}

Začetek dolgoročne elektronske hrambe v slovenski upravi:

trenutno stanje in scenariji prihodnosti

arhiviranje. Stanje kaže, da so mnogi organi na dobri poti, da kmalu začnejo pravnoveljavno dolgoročno elektronsko hrambo, drugi pa bodo morali še marsikaj storiti tako na področju upravljanja elektronskih dokumentov kot na področju hrambe le-teh. Vzpostaviti bo treba ustrezen nadzor, ki bo urejal uvedbo takih pravil. Pravila so vsekakor korak v pravo smer, ki bo posredno uredil tudi samo elektronsko poslovanje in mogoče še določene organizacijske elemente, ki jih nekateri organi javne uprave še niso uvedli (elektronska evidenca, klasifikacijski načrt ipd.).

Mag. Mitja Dečman je asistent za področje informatike na Univerzi v Ljubljani, Fakulteti za upravo, kjer se poleg pedagoške dejavnosti uspešno ukvarja z raziskovalno, hkrati pa sodeluje ali vodi različne projekte tako interno, na ravni Slovenije ali v okviru Evropske unije. Področje raziskav si od končanega magistrskega študija na Fakulteti za računalništvo nenehno dopolnjuje in razširja: s področja strojne in programske opreme na področje informatike, razvoj informacijskih sistemov, e-uprave in v zadnjem času na specifična področja varnega elektronskega poslovanja, digitalnega podpisovanja in časovnega žigosanja ter v okviru doktorske disertacije na področje dolgoročne elektronske hrambe in še posebej zagotavljanje avtentičnosti. 


\section{Literatura}

- $\quad$ Arhiv republike Slovenije. (2006). Enotne tehnološke zahteve 1.0. Arhiv republike Slovenije, 2006.

http://www.culture.gov.si/fileadmin/mk.gov.si/pageuploads/Ministrstvo/Drugo/ novice/ETZ.pdf.

- $\quad$ Arhiv Republike Slovenije. Moreq: Model za upravljanje elektronskih dokumentov. Arhiv Republike Slovenije, Ljubljana, 2005.

- Blanchette, J. F. (2003). Digital Archiving Strategies for the Long Term. eArchiving for Posterity, InterPARES 2 project. British Columbia, Kanada: University of British Columbia.

- Center for Information Policy, University of Maryland. (2005). Best practices in electronic records management. Maryland, ZDA: University of Maryland.

- $\quad$ Cohasset associates inc. (2005). 2005 Electronic Records Management Survey. Retrieved 6. 14., 2004, from http://www.MERresource.com/whitepapers/survey

- Delmas, B. (2001). Archival science facing the information society. Archival Science (pp. 25-37). Netherlands: Kluwer Academic Publishers.

- Dollar, C. M. (1998). Authentic electronic records: strategies for long-term access. Vancouver: Cohasset Associates.

- $\quad$ Garrett, J., \& Waters, D. (2004). Preserving Digital Information: Final Report and Recommendations. ftp://ftp.rlg.org/pub/archtf/final-report.pdf.

- International Council on Archives, Committee on Current Records in an Electronic Environments. (2005). Electronic Records: A Workbook for Archivists. Paris, Francija: International Council on Archives.

- Lavoie, B. (2000). Meeting the challenges of digital preservation: The OAIS reference model. OCLC Newsletter (243), 26-30.

- MacNeil, H. (2001). Authenticity Task Force Report. www.interpares.org.

- Novak, M. (2004). Problem mobilnosti podatkov v arhivski teoriji in praksi. Sistemi za upravljanje z dokumenti: zbornik posvetovanja DOK_SIS 2004 (pp. III-1 III-12). Ljubljana, Media.doc.

- Rothenberg, J. (1998). Avoiding Technological Quicksand: Finding a Viable Technical Foundation for Digital Preservation. Council on Library and Information Resources. http://www.clir.org/pubs/reports/rothenberg/pub77.pdf.

- The Digital Preservation Coalition. (2006). Mind the Gap: Digital Preservation Needs in the UK. Ariadne. www.ariadne.co.uk/issue48/semple-jones/.

- Uredba o upravnem poslovanju. Ur. list RS, št. 20-690/2005. 
Mitja Dečman

Začetek dolgoročne elektronske hrambe v slovenski upravi:

trenutno stanje in scenariji prihodnosti

- Uredba o varstvu dokumentarnega in arhivskega gradiva. Ur. list RS, št. 86/2006.

- Zakon o elektronskem poslovanje in elektronskem podpisu. Ur. list RS, št. $57 / 2000$.

- Žumer, V. (2002). Od nastanka zapisov do izročitve arhivskega gradiva v slovenski javni upravi. Arhivi, 25 (2), 1-14.

- Zakon o varstvu dokumentarnega in arhivskega gradiva ter arhivih. Ur. list RS, št. 30/2006. 


\section{SUMMARY}

\section{THE BEGINNING OF THE LONG-TERM ELECTRONIC PRESERVATION IN THE SLOVENIAN PUBLIC ADMINISTRATION: CURRENT STATE AND FUTURE SCENARIOS}

Today's information society makes use of information technology (IT) in various ways every second; each segment of society does that in its own way and with its own specific goals. The advantages of IT are not only put to good use in everyday work with electronic data, but also in the field of document preservation to which it brings numerous advantages both within the business environment as well as within national archives. Among the advantages are better accessibility ( 24 hours a day, seven days a week, remote access, various client access) and a better and quicker search, while among the disadvantages are an increased need for IT, experts and high-technology knowledge, and higher costs since electronic preservation is introduced alongside the classic one which will be practically always necessary due to the existing amount of paper documents.

If digital documents are stored in the original form without any changes, the access to them will in time become increasingly harder if not impossible, which does not apply to the classic forms (paper, parchment, stone etc.) as much. So it is necessary to preserve the physical medium of digital documents, the ability to interpret document formats and the ability to interpret the contextual dimension of a document. One of the more important functions of the digital preservation is undoubtedly ensuring authenticity and integrity due to the characteristics of digital form that differ from those of the classic one. Digital form itself does not guarantee protection against changes in the contents in the way we are used to with documents in paper form. A key reason for this is that in paper form the contents are inseparably connected to the medium - i.e. paper, in digital form that is not the case. All this requires a long-term and constant performing of preservation activities.

Both in the world and in Slovenia society adapts to new technological challenges, which is true also of document management and archiving. Everywhere sooner or later changes are followed by shifts in law, in other words, by the preparation of adequate new legislation and changes in the 
Mitja Dečman

Začetek dolgoročne elektronske hrambe v slovenski upravi: trenutno stanje in scenariji prihodnosti

existing one. Umbrella laws usually deliberately do not determine and limit the technology itself, which makes them open to future changes brought about by rapid technological development. In Slovenia, electronic preservation and archiving is now regulated by a set of three pieces of legislation: the Protection of Documents and Archives and Archival Institutions Act (PDAAIA, 2006), the Decree on documentary and archival material custody (DDAC, 2006) and the Uniform Technological Requirements (UTR, 2006), in 2007 followed by the Check List for Checking the Conformity of Internal Rules For the Long-term Digital Preservation with PDAAIA (KSpNP, 2007). Thus it was made possible that in Slovenia documents can be legally converted from paper to digital form, from one digital form to another in a legally valid way (e.g. into a form for the long-term preservation if the retention period exceeds 5 years); and such documents are stored without the need to preserve the paper original as well. The preservation of captured material (reproduction) has therefore an equal status with the preservation of original documents if the captured material has preserved all the effects of the original material (the usability of the contents of the material). Thus the preservation of original documents is no longer necessary (format migration or media refreshing, for example, is allowed).

In the field of digital archiving very little empirical research has been done so far since this is still a rather undeveloped field. Most work has been done in various projects of a theoretical or technical nature, and on the development of applications, which based on scientific findings, different standards and on experience with classic archiving offer the first solutions for the long-term digital preservation. Among the most wellknown research projects we should mention the empirical research done in Great Britain in 2005 analysing the current state in this field in the country (The Digital Preservation Coalition, 2006), the research by Cohasset Associates Inc., AllM International and ARMA International focusing on document management from the aspect of the long-term accessibility to these documents (Cohasset associates inc., 2005), and the research by the University of Maryland analysing the current state of electronic document management and their long-term preservation in the USA (the Center for Information Policy, University of Maryland, 2005).

The research on the current state in Slovenia was done at the beginning of 2007. The target population was divided into groups and consisted of municipalities $(N=193)$, administrative units $(N=58)$, ministries and 
bodies within the ministries ( $N=55)$, universities and faculties $(\mathrm{N}=43)$, and the rest of the state administration ( $N=112)$ : top state administration bodies $(N=5)$, governmental services $(N=16)$, other institutions, agencies, commissions and institutes ( $N=21)$, the Health Insurance Institute of Slovenia and its units $(\mathrm{N}=7)$, and the Department of Social Services of the Republic of Slovenia and its units $(\mathrm{N}=63)$. The analysis of the current state in document management has shown that the respondent bodies in addition to legislation on records management in force also use in large part $(45 \%)$ additional regulations, instructions or strategies; almost all bodies use classification plans (87\%) and carefully determine retention periods both for paper and electronic documents (84\%). The respondent bodies keeping records of documents do that mostly electronically $(76 \%)$, as stipulated by the legislation for state administration bodies.

Digitalization is used by the $28 \%$ of the respondent bodies, especially by the respondent administrative units $(51 \%)$ and by the ministries and the bodies within the ministries (62\%). In the public sector, there are $55 \%$ of the respondent bodies that continue to treat the paper original as solely legally valid, the rest treat the original and the appropriately digitalized document as equivalents. Many bodies use internal regulations for email management (36\%); administrative units (78\%) stand out in particular. The answer to the question how they store emails and attachments is surprising - the majority of bodies (65\%) print out emails and attachments and manage them as paper documents.

Surprisingly, no less than $15 \%$ of the respondent bodies in the public sector do not feel the need for electronic preservation, among those who do feel this need $85 \%$ of them do not have any solution yet. Almost half of the respondent bodies are without a prepared strategy or plan for document preservation in electronic form. On average, only a quarter of the questioned organizations state that current organizational and technical solutions guarantee a safe and verifiable electronic preservation. Media refreshing on a physical level and format migration on a software level are definitely part of the technical phases of electronic preservation. The results point to an interesting finding that media refreshing is quite frequent $(27 \%)$, while format migration is an operation where the answer is rarely "being carried out" or "being planned" (11\%). Only a few bodies (around $10 \%$ ) include funding for electronic preservation in their annual financial plans, but it can be noticed that there are more such organizations in those groups of respondents where there are more funds in general. To 
Mitja Dečman

Začetek dolgoročne elektronske hrambe v slovenski upravi:

trenutno stanje in scenariji prihodnosti

preserve electronic documents the respondent bodies most frequently copy the documents on a mobile medium or simply print them out, while in the two groups of administrative units and ministries the use of archive servers or archive systems prevails. The respondent bodies in the public sector in Slovenia see the lack of adequate machine and programme solutions for electronic preservation as the main problem of the long-term electronic preservation; the lack of knowledge and financial resources come second.

As shown by the results, the Slovenian public administration is well on its way to guarantee itself a safe digital future and to enable the future generations to browse digitally through the past. The Slovenian legal basis is one of the most advanced in the world and guarantees both the public and the private sector adequate digital safety. As was concluded in our project and other research projects around the world, the Slovenian administration should not rely only on the adopted legislation and internal regulations in the bodies for the long-term electronic preservation. The current state shows that many bodies are well on their way to begin the long-term electronic preservation in a legally valid way, others still have a lot of work to do regarding electronic document management as well as electronic preservation. An adequate supervision should be established to regulate the introduction of such regulations. However, the adopted legal basis as well as other ensuing activities of the state are definitely a step in the right direction, which will not regulate only the long-term electronic preservation, but also indirectly e-business of public administration and certain organizational elements some bodies in Slovenian public administration still lack (e.g. electronic records, a classification plan etc.). 